\title{
Introduction: \\ The Great Woman Writer, the Canon, and Feminist Tradition
}

In a 1941 collaborative obituary of Virginia Woolf, the novelist Rose Macaulay, herself a descendant of literary Victorians, records Woolf's mimicry of a Victorian voice: " 'Is this a great age?' [Woolf would ask] or, 'can there be Grand Old Women of literature, or only Grand Old Men? I think I shall prepare to be the Grand Old Woman of English letters. Or would you like to be?" " (317). It is a brief moment in a short memoir, possibly invented as a novelist invents dialogue. But the gloss on Woolf's relation to literary tradition is telling: Woolf, with mock solemnity as well as genuine skepticism about the notion of unique literary greatness, seems to acknowledge her peculiar role as the leading woman writer of her age. She had succeeded to the title that only George Eliot had won before her, that of the Grand Old Woman of English Letters. The title, as Woolf's remark suggests, was deeply ironic, since the grandeur or greatness seemed calibrated with the writer's ability to suppress the disqualification of womanhood. The female laureate might as well have been male, she had become so representative of the age. ${ }^{1}$ Yet Macaulay's memoir constructs the kind of female literary tradition that has become so dear to feminist

${ }^{1}$ Such is the logic implied in T. S. Eliot's contribution to the same tribute; Woolf appears to belong to the masculine category of "great writer." T. S. Eliot affirms that Woolf became "the centre ... of the literary life of London," "the symbol" of the "Victorian upper middle-class" cultural tradition. T. S. Eliot dwells more on his own views than on Woolf herself (the memoir begins, "It has only been under peculiar conditions that I have ever been able to interest myself in criticizing . . . contemporary writers" [313]). Other contributors to this obituary include Vita Sackville-West, William Plomer, and Duncan Grant, in two issues of Horizon: A Review of Literature and Art; 3:17, 18 (1941): 313-27, 402-6. In 1928 Woolf suspected that she and Macaulay were jealous of each other's success (VW Diary 3: 185). 
critics who follow Woolf; Macaulay's first sentences create a literary heroine: " 'She had animation; she had sensibility; she had elegance, beauty and wit.' Thus Jane Austen, doing her descriptive utmost, might have approved Virginia Woolf." Through a timeless Austen's approval of Woolf, Macaulay performs for Woolf the memorial service that the latter had performed for so many women of letters before her, but for no one more fully than for George Eliot.

Macaulay touches on some of the same elements that we find in Woolf's 1919 centenary essay on George Eliot. She focuses as Woolf does, for instance, on the predecessor's oracular presence in literary circles, but she notes that the twentieth-century sibyl is irreverent in a most un-Victorian manner. Woolf's admiring visitors encountered not an edifying discussion of culture but the sheer "entertainment" of "a flashing, many-faceted stream" of "conversation." The pilgrims to Eliot's house, the Priory, according to Woolf encountered the full force of Eliot's unplayful intelligence. Yet it is manifestly difficult to arrive at an accurate understanding of the famous woman writer of the past. Reassessing Eliot, Woolf marvels at "the credulity ... with which, half consciously and partly maliciously, one had accepted the late Victorian version of a deluded woman who held phantom sway over subjects even more deluded than herself" ("GE" [1919] 150). Like Macaulay's obituary portrait of Woolf, the 1919 elegy, "George Eliot," strives to reconcile a peculiar disparity between the private woman and the public persona of the famous writer, as though both women of letters were reclusive outsiders yet full participants in the spirit of the age. ${ }^{2}$ I seize on Macaulay's playful evocation of Woolf's speech as a guide to Woolf's understanding of her own vocation: she was to be-playfully - the grand old woman of English letters in her age, as she acknowledged Eliot had been in hers. To win the title would be to struggle with an idea of cultural history that excluded the personal qualification of womanhood from the realm of greatness.

This study of Eliot and Woolf addresses the problem of greatness

\footnotetext{
${ }^{2}$ Macaulay notes the great woman writer's ambiguous persona as both private and representatively public: "[Woolf] was sometimes pleased ironically to pose as the recluse who watched life from a quiet, drab corner." Yet "her going seems symbolic of the end of an age," Macaulay writes. Woolf consciously reenacted the ritual of visits to the great writer, as Daniel Mark Fogel recalls with regard to her response to Henry James. In 1907 she wrote to Violet Dickinson, "But when I am old and famous I shall discourse like Henry James" (VW Letters 1: 306). In one version of "A Sketch of the Past," she wrote, "I remember . . . the ceremony of our visits to great men. . . . Greatness still seems to me a positive possession; booming; eccentric; set apart; something to which I am led up dutifully by my parents. . . . But it never exists now" (Fogel 56-58). That the greats were men of the past did not prevent her reviving a female legacy of a different greatness.
} 
for the woman writer, not only in biographical terms-how does she achieve "greatness"? - but in terms also of a feminist revision of history to admit the not-"great": the selfless, feminine, common, other. I hope to establish the extent to which Eliot and Woolf thought in common within a certain feminist tradition that affirms a supposed feminine selflessness as it rejects the masculine self-assertion that has conventionally fueled notions of greatness. While I wish to assess the implied debt that Woolf owed to Eliot (arguably her most substantial literary inheritance), this is not so much an "influence" study as it is a study of an ideal of feminine influence-as antidote to masculine egotism - that both authors incorporated in their texts with much equivocation. How did these authors, intent on their own success within a masculinist tradition, redefine heroism and greatness in feminist terms? Eliot's narrator sardonically observes Will Ladislaw's and Mr. Brooke's discomfort under a noble admonition from Dorothea: "A man is seldom ashamed of feeling that he cannot love a woman so well when he sees a certain greatness in her: nature having intended greatness for men" (M 285). Eliot, like Woolf afterher, is quite skeptical about the "intention of nature" argument that separates male and female spheres according to gender stereotypes-man for greatness, woman for self-sacrifice. Yet in both Eliot's and Woolf's writings we can detect a fondness for feminine self-sacrifice, a nostalgia for separate spheres and for an essential, inborn gender.

Much of my argument in the following chapters turns around the vexed dualism and essentialism of such thinking, particularly the heavily gendered dichotomy between public and private spheres. First, the biographical question: How could the Grand Old Women of English Letters be both "women" and "great" in a tradition that defined greatness, like history itself, in terms of the masculine, public "sphere" of action? As Mary Poovey has shown, the Victorians found diverse uses for a cult of the impenetrably private sphere of woman, but in the process they subverted the binary opposition of spheres on which the cult rested (8-9, 21-22). Thus these women of letters can be seen traversing, in the design of their careers and authorial personas, the culturally defined spheres of womanhood and of masculine greatness. Second, their works can be read as historical narratives that promote commerce between the spheres-all private life has its history, all history is determined by the developments of private lifein specifically gendered terms.

These unusually privileged women writers give utterance to history's silencing of women (if not lending speech to women themselves). Woman, most simply, figures as the other in history-even as the 
"other half," the lower classes, are feminized. To speak from the point of view of this other, as these authors' works in part attempt to do, might be to challenge the hierarchy of the spheres, subverting the predominance of the masculine self, the public realm, and the ruling classes. Or it might remake woman in man's image, raise the common life to the condition of the middle class, reaffirm the masculine model of the ego and authority. According to the logic of this view of sexual destiny, in attaining authority within tradition women lose their privacy and they may lose the virtues of their difference, violating the sacrificial feminine ideal that I will call the ideology of influence. Eliot and Woolf appear to launch an attack on masculinist mythparticularly egotism-in the form of a celebration of the feminine selflessness and influence that have traditionally been considered the harmless underside of patriarchal myth. The harm that feminine influence might do to patriarchy had of course been underestimated, as we see in so many Victorian texts, but the harm this ideal might do to its own exemplars, the characters and women authors themselves, bears a careful reexamination.

The most fundamental challenges to the woman who wishes to become a "great writer" in a male-dominated literary tradition are, on the one hand, to suppress the modifier "woman"-though how this is done remains mysterious even in the instances of literary women's acknowledged "greatness" ${ }^{3}$-and on the other hand, to come to terms with the masculine norm inherent in the individualistic concept of greatness. No woman writer, of course, has ever successfully proved the complete irrelevance of her womanhood, but at the height of her reputation for greatness her sex must somehow seem either incidental, intriguing, or all the more cause for admiring her transcendence of ordinary life. Eliot and Woolf come to us almost uncontested as the greatest British Victorian and modern women novelists, and this chain of dubious modifiers helps us avoid deciding on "real" relative merit, forestalling any comparison, for example, to Dickens or Joyce. The literary lives and narrative strategies of Eliot and Woolf, however, shun the delimitation "woman."

Women writers face not only the obstacle of preconceived womanhood, but also the perhaps more daunting problem of the conception of greatness itself. To be great, in patriarchal culture, is to resemble the male hero, and certainly it is to have some standing in a public

${ }^{3}$ Ellen Moers illustrates this difficulty, faced even by the female feminist critic, when she begins her preface to Literary Women: The Great Writers: "The subject of this book is the major women writers, writers we read and shall always read whether interested or not in the fact that they happened to be women" (ix). 
story; in modern, post-Romantic European culture, to be great is to embody an individualistic ideal. The great artist, at least in most popular accounts, is urged to forfeit all conscious "thinking in common"; he must be original. Woolf's vision of tradition as a "thinking back through" rejects the artist as self-made solitary, especially by urging women to think back through "our mothers," since mothers are notorious for threatening the dissolution of the ego, their own as well as others'. The institutionalized ambivalence toward the mother that Nancy Chodorow and Dorothy Dinnerstein have analyzed haunted the tradition that Eliot and Woolf worked within, and undoubtedly influenced their own childless careers and their own efforts at greatness. As though to become the grand and old mothers whom later generations would think back through, they threaten their characters with the dissolution of ego (they are especially severe on heroines), and they cultivate a selfless authorial persona, dedicating themselves to a collective cultural progress.

Eliot was accepted by her contemporaries as a sage who served the advancement of the common life. Her doctrine, if it had to be expressed in a sentence, teaches the sin of egotism and the virtue of selfdenying fellow-feeling. Egotists like Rosamond Vincy and Gwendolen Harleth show that femininity and egotism readily coincide, but society lends women one advantage in their moral education by teaching them to yield to others in spite of their unruly desires. The narrator of Middlemarch observes: "We are all of us born in moral stupidity, taking the world as an udder to feed our supreme selves: Dorothea had early begun to emerge from that stupidity, but yet it had been easier to her to imagine how she would devote herself to Mr. Casaubon ... than to conceive ... that he had an equivalent centre of self, whence the lights and shadows must always fall with a certain difference" (156-57). Less overtly didactic, Woolf teaches much the same doctrine and makes the gender dynamics of egotism more explicit, repeatedly mocking the phallic "I, I, I" (RO 103-4; TL 160 ; Y 361 ). Her work increasingly enacts the breakdown of ego boundaries-as in the six equivalent centers of self in The Waves-to turn to the first-person pronoun "we." Although at times she concedes that women may share with men a desire for dominance, she finds hope in women's conditioning if not in their nature; as outsiders, they will emerge from moral stupidity. ${ }^{4}$ Any woman might resist the loss of supreme self,

\footnotetext{
${ }^{4}$ Naomi Black notes Viscountess Rhondda's query about Three Guineas: “In my heart I find . . . all the pride, vanity and combativeness I ever see in men." Woolf replied, "[Such feelings] are in us of course; I feel them pricking every moment. But again they have so little encouragement in us. ... If we emphasise our position as outsiders and
} 
might wish to declare the centrality of her "I," but she cannot avoid seeing with a certain difference, athwart the male point of view. Such moral awareness cannot, however, earn her cultural eminence-or so the myths of Dorothea, Mrs. Ramsay, and other women in the works of Eliot and Woolf imply-unless true greatness can be redefined as a participation in an historical common life, "our" life.

In my view, Eliot and Woolf succeed in redefining greatness in this way; their greatness for me-their almost inexhaustible worthiness to be read and reinterpreted-is due largely to the persuasiveness of the myth they variously narrate, the myth of a shared, progressive life beyond individuality. Yet in attributing the myth to them, I identify their individuality. They appear as distinct cultural deities in a mythology of impersonality. Quite simply, the tension of this contradiction propels this book.

My ironically charged worship of the great women of letters is conditioned by changing histories of reception; in particular, this study would have been impossible without the foundation of feminist criticism in the American academy. At the same time, this book inevitably lives in the world of studies of canonical authors. We-a suspect pronoun that I have decided to use, as much as possible in the diversified yet collective spirit in which Eliot and Woolf try to use it-we cannot help mythologizing the writer whom large numbers of people have agreed to read, and whom we in turn have agreed to talk and write about. The literary name perpetuates the myth, so that every time I write "Eliot" or "Woolf," or in the more specialized myth I am constructing here, "Eliot and Woolf," an illusion of a unified author or pair of authors rises to solicit our desire to keep reading and talking. It appears impossible to look at authorship or discuss canonical authors without at moments believing that the texts we have read are the woman or man who wrote them, a knowable, historically fixed source. But I try to recall that the grand old women of letters are for us textual constructs, even when considered as apparently real, biographical beings. It is precisely to observe the workings of such myths that I have chosen to study canonical women authors, trying meanwhile to keep myself from falling into great-traditionism, cultof-genius-ism, Eurocentrism, and other acts of exclusion that I consciously deplore. In reconstructing the tradition of Eliot and Woolf, then, I hope also to unsettle our reading of it, directing our practical need for a female literary tradition into a more considered revision of

come to think it a natural distinction it should be easier for us than for those unfortunate young men" (Black, "Woolf and Women's Movement," 192, citing VW Letters 6: 23637). 
the terms on which we grant authorial greatness or "traditional" status. And let me say at the outset that "I" make no claim to unique originality; I am "thinking in common" in a tradition, one that most will agree in tracing back to that original, Woolf (with her debts to Coleridge, Arnold, and their debts . . . to Sappho, Felicia Hemans, or some hypothetical Mrs. Ayres?).

\section{Victorian to Modern, Eliot to Woolf: The Genealogical Record}

As the obituary with which I began reveals, the literary executor is charged with the task of memorializing the past author in terms useful for unfolding literary history in the present. Thus Woolf's reading of Eliot, as we shall see, has a complex bearing on her self-construction as a woman of letters as well as on her sense of modernity, of living in a new age. For Woolf, the very definition of her "age" raised gender issues obscured by the standard tradition, so that she generally resorted to metaphors of the family romance rather than the vocabulary of science employed by T. S. Eliot, Pound, or the Futurists (Ian Bell 181, 191). The title as well as the substance of Woolf's modernist manifesto, "Mr. Bennett and Mrs. Brown," obliquely suggest that the famous change in human character is no gender-neutral aesthetic transition but a challenge to patriarchal dominance, as my later discussions of this essay will show. But Woolf is as capable as T. S. Eliot of erasing personality and gender in her depiction of cultural history.

Like other writers after the turn of the century, she covered the tracks that led her out of the Victorian age. In "How It Strikes a Contemporary," she claimed to have lived through a cataclysmic upheaval even as she invoked a favorite Victorian image of geological epochs:

We are sharply cut off from our predecessors. A shift in the scalethe sudden slip of masses held in position for ages-has shaken the fabric from top to bottom, alienated us from the past and made us perhaps too vividly conscious of the present. Every day we find ourselves doing, saying, or thinking things that would have been impossible to our fathers. And we feel the differences which have not been noted far more keenly than the resemblances which have been very perfectly expressed. 
Critics who are no longer direct successors of the Victorians now sense that it is the resemblances between the moderns and the Victorians that have been overlooked. Woolf contributed to a rhetoric of "novelty" that enabled the significant innovations of modernist writers ("How It Strikes a Contemporary," CE 2: 157-58; a title borrowed from Browning), and she seems at times capable of using a phrase like "our fathers" without wincing. But the paternal metaphor seems peculiarly real in Woolf's case, as she held what T. S. Eliot calls "a kind of hereditary position in English letters" (315); her understanding of the generational and gender conflict in the family of letters was most immediate.

Woolf was herself reared among literary Victorians, as her portraits of Mr. Ramsay (based on Leslie Stephen) and Mrs. Hilbery (modeled on her aunt Anne Thackeray Ritchie) testify. Yet for the most part she obscured the fact that her work had a corresponding upbringing in Victorian literature. Indeed, she seemed to feel that the career of the eminent writer "Virginia Woolf" would never have been born at all if the figures of father and mother-her real parents and the literary prohibitions they had come to represent-had not died. In "Professions for Women," she advises the young woman writer to slay "The Angel in the House" (59), the Victorian ideal (invoked perhaps more religiously in our feminist retrospectives than at the time) that haunted Woolf in memories of her own mother, Julia Stephen (Rosenman, Invisible Presence, 15, 70). Similarly, many critics have noted Woolf's sense of release from Leslie Stephen's prohibitive influence: "Father's birthday. He would have been 96, 96, yes, today; and could have been 96, like other people one has known: but mercifully was not. His life would have entirely ended mine. What would have happened? No writing, no books;-inconceivable" (VW Diary 3: 208). The absence of both parents was as instrumental to her writing as the modernist sense of having been "sharply cut off from our predecessors." Woolf's great "elegy," To the Lighthouse, for example, would have been inconceivable without the deaths of her parents, as Margaret Homans points out (285). ${ }^{5}$ As Woolf put it, "writing The Lighthouse laid them in my mind" (VW Diary 3: 208).

Works such as To the Lighthouse succeeded in laying to rest-and simultaneously marking with indelible epitaphs_-Woolf's literary as

${ }^{5}$ Homans effectively traces Woolf's ambivalence toward the representation of the mother, who like Mrs. Ramsay has both access to the literal (pre-oedipal) language of maternal presence and a well-trained subservience to the figurative discourse associated with male mastery (279-81). 
well as literal forebears. She betrays her sense that her "resemblances" to great predecessors would be "perfectly expressed." Woolf's impressive innovations in her 1927 novel may distract us from her equally impressive reworking of literary antecedents, in such details as the fact that Minta Doyle loses the final volume of Middlemarch on the train (Homans 277-78), and in larger patterns such as the madonnalike grandeur of Mrs. Ramsay, a modern Saint Theresa or Dorothea Brooke grown up (and married to a counterpart of Casaubon). Such reworkings are complexly ironic and at the same time surprisingly in harmony with the precedents offered by Eliot's works. Woolf laid George Eliot to rest, like another Mrs. Ramsay, in her centenary essay of 1919 (Jacobus, Reading Woman, 28-29), while perpetuating Eliot's literary spirit in her own writings.

Searching through English literary history like a genealogist, Woolf never fixed her own pedigree, male or female. Male writers "never helped a woman yet," Woolf asserts (RO 79), naming some (such as Thackeray and Dickens) who very much assisted her reading-apprenticeship in her father's library. In the facetious preface to Orlando, she obliquely honors her debt to a literary tradition almost exclusively male: "Defoe, Sir Thomas Browne, Sterne, Sir Walter Scott, Lord Macaulay, Emily Brontë, De Quincey, and Walter Pater" (vii). More than clownishly turning this tradition on its head, however, Woolf elsewhere parades before our eyes what appears to be a brand new tradition, the succession of her literary foremothers: "many famous women, and many more unknown and forgotten, have been before me, making the path smooth, and regulating my steps" ("Professions for Women" 57). Smooth and regulated may not be equally positive qualities for a writer trying to make her own way. But on the whole, Woolf's outlook on the female literary tradition is less adversarial than we have been led to expect, modeling our study of women writers on a separate-but-equal anxiety of influence. ${ }^{6}$ In spite of Woolf's warning to slay the motherly Angel in the House, she seems eager to rescue rather than to slay precursors more overshadowed than overshadowing.

The individual author's claims to originality should be waived, ac-

\footnotetext{
${ }^{6}$ Sandra Gilbert and Susan Gubar draw on Woolf in their constructions of a female tradition of "anxiety of authorship," but Woolf's depiction of the literary landscape is far less bloody than The Madwoman in the Attic $(187-88,17)$. See Gilbert and Gubar's " 'Forward into the Past,'" No Man's Land 1: 192-93: "In the twentieth-century . . . Freud-derived Bloomian paradigms like . . . our own 'anxiety of authorship' must give way to a paradigm of ambivalent affiliation." See Showalter, Sexual Anarchy, 60, 77.
} 
cording to Woolf, especially as women authors recognize the sufferings they have in common:" "For masterpieces . . . are the outcome of many years of thinking in common, . . . so that the experience of the mass is behind the single voice. Jane Austen should have laid a wreath upon the grave of Fanny Burney, and George Eliot done homage to the robust shade of Eliza Carter-the valiant old woman who tied a bell to her bedstead in order that she might wake early and learn Greek" (RO 68). Like Austen and Eliot, Woolf owed a tribute to her forerunner, but she paid it most in a few critical essays and in the kind of covert elegy I have briefly noted in To the Lighthouse. Woolf seems content that the public tributes seldom be paid, since the most characteristic yield of a woman's literary tradition is the masterpiece of submerged provenance: it is by "Anon." While Woolf more than anyone before labored to restore a female literary tradition, and explicitly honored a number of female predecessors, most notably the Brontës and Austen besides Eliot, she left us to detect in her far from anonymous masterpieces how much she owed to them. At the same time, she labored to be beautiful in a tradition that regarded itself as beyond gender or personality. The modern Grand Old Woman of English Letters, like the Victorian, paradoxically aspired to literary greatness, on the one hand by suppressing her identity as a woman and honoring the great tradition, and on the other hand by striving to dismantle the tradition of "our fathers."

This very problem, of how to be a "great" writer yet a woman, focuses the reasons for considering Eliot as the most important of Woolf's ancestors. As I shall argue, criticism of women writers almost invariably follows a biographical convention that divides artistic vocation from the normative plot of a woman's life, so that, for example, the wife and mother, if she writes, cannot be a great writer. Woolf at times seems to accept uncritically the dominant literary canon and standards of female greatness, as in her Mt. Rushmore of Jane Austen, Charlotte and Emily Brontë, and George Eliot, none of whom was conventionally married during her active writing career, and none of whom bore children. ${ }^{8}$ Yet Eliot more than the others escaped womanly dependency on family: neither Austen nor the Brontës ever held a place in intellectual circles as Eliot and Woolf did; even Charlotte

${ }^{7}$ Janet Todd discusses Woolf's autobiographical portrayal of women writers as "female heroes or distressed ladies of sensibility," contrary aspects of her own self-portrait (1079).

${ }^{8}$ See Showalter, Literature, 6-7. In her writings, Woolf helped rescue many lesserknown women writers and acknowledged some who integrated women's roles and professional writing. See M. Barrett, Introduction. Yet it seems that one of Woolf's criteria for greatness is the exemption from the usual womanly life. 
Brontë was only a sojourner in literary London. ${ }^{9}$ At the same time, Eliot must have seemed nearly part of Woolf's own family, having been friendly with Leslie Stephen and his sister-in-law, Anne Thackeray, both of whom somewhat skeptically joined in the author-worship on Sundays at the Leweses' Priory. ${ }^{10}$ As important for Woolf as were many other figures, male and female, on the literary family tree, none but Eliot illustrated just how divorced the public persona of a great woman of letters might have to be from the traditional feminine role, defined by its privacy.

In her critical writings, Woolf might seem to disagree with my claim that Eliot is her most important female ancestor. Of the four "great" women writers of the English nineteenth century, Woolf often seems to give precedence to Austen rather than Eliot; Austen earns praise (as she did from George Henry Lewes and other Victorians) for her Shakespearean, "incandescent" unself-consciousness ( $\mathrm{RO} 58,71$; "Phases of Fiction," CE 2:76; "Jane Austen" 109-20). Moreover, only Austen in this circle of great literary women was always the lady: in addition to her impeccable family credentials, she obeyed the commandment that women must "charm" rather than challenge (Todd 111-14). Paradoxically, in A Room of One's Own, Emily Brontë is linked with Austen for her single-minded disregard of the commandment to be ladylike. In effect, Woolf allows Emily and gentle Jane to drop one modifier, "woman," and add another, "great," because their artistic manners are self-effacing enough to remain feminine even in greatness. They have no biographies: readers know little about them, and their personal grievances never intrude upon the page. Charlotte Brontë and Eliot, on the other hand, are more easily criticized because they became notorious: their lives became matter for public debate.

The insistent personality of a writer like Charlotte Brontë offends a certain aesthetic code that dominated Woolf's day, and that had special implications for women writers. As Andreas Huyssen observes, the modernist dictum that art must be autonomous, non-referential, and detached from "everyday life" expresses in itself a strong bias against women and mass culture (53-54). Woolf curiously adapted this bias to her feminism by characterizing authoritative personality as masculine

\footnotetext{
${ }^{9}$ Elizabeth Barrett Browning and Elizabeth Gaskell, perhaps because of their wellknown personas as wives and mothers, failed to engage Woolf's competitive interest in the same way, though she took pains to resurrect Barrett Browning in Flush and elsewhere.

${ }^{10}$ Stephen noted in his Mausoleum Book that "one had to be ready to discuss metaphysics . . . and offer an acceptable worship" at the Priory; Lady Ritchie wrote, "The shrine was so serene and kind that this authoress felt like a wretch for having refused to worship there before" (quoted in Showalter, "The Greening of Sister George," 293).
} 
(Minow-Pinkney 15), so that writing beyond self-conscious personality might be considered writing "as a woman" or as an androgynous, Shakespearean mind (it is ironic that Shakespeare, the national hero, should be invoked as the impersonal ideal). Instead of achieving the universality of art, which Woolf concurrently figures as a feminine mode of egoless greatness, Charlotte Brontë declares herself to be a woman. One must write "as a woman who has forgotten that she is a woman," according to this aesthetic prescription, whereas Brontë allowed autobiographical protest about woman's lot to encroach on her novels ( $\mathrm{RO} 96,71-73$ ).

Woolf certainly places Eliot higher in the pantheon than Brontë, in part because Eliot utters no personal outcry, though Woolf does detect awkward self-portraiture in Eliot's heroines. ${ }^{11}$ It might almost seem that Eliot achieved the indifference to her womanly role that Woolf sought in the woman writer. Escaping the woman's sphere of the matchmaking novel of manners, Eliot according to Woolf was "one of the first English novelists to discover that men and women think as well as feel" ("GE" [1921]). Conversely, Eliot's command of the uncharming realm of thought seems to strike Woolf as a biographical monstrosity. Eliot moreover betrays the woman's "difference of view" ("GE" [1919] 160) with her masculine pseudonym and style (RO 80).

Eliot certainly breaks Woolf's rather unhelpful commandment to write as women write (and how is that?), though she does obey the concurrent commandment to write without (apparent) awareness of her own female personality. Perhaps Eliot makes her flight from female personality a little too obvious. For Woolf, the woman writer who writes like a man, instead of making a virtue of her limitations as Austen does, calls attention to those limitations (as Eliot was quick to point out in her own criticism of women writers). The fault of manliness, however, is at the same time for Woolf a major source of Eliot's importance, as it enabled Eliot to become the preeminent English woman of letters, largely escaping the usual patronizing criticism of female writers and extending the narrow sphere of the novel that Austen had so elegantly plotted out. Imagine a respectably genuine Mrs. Lewes being taken seriously by young Oxford men; imagine The Wit and Wisdom of Mrs. John Cross. Instead, the great literary figure overcame the identity of the fallen woman and eventually the male persona as well. As Gillian Beer puts it, Eliot transforms "the male

\footnotetext{
${ }^{11}$ When Woolf facetiously aimed to "sum up" her predecessor "once and for all" in the centenary essay, she noted the central problem of Eliot's heroines. Her reading notebook declares, "You may dislike her heroines but you don't get the full flavour unless you consider them" (Silver, Notebooks, 201-2).
} 
persona . . . into her own image as a human scribe who is, historically, a woman" (George Eliot 16). Lauded as novelist and cultural critic, the colleague of leading intellectuals, George Eliot seemed to define the broadly "human" role Virginia Woolf adopted for herself.

Not long after Woolf's first article on Eliot appeared in 1919, she wrote in her diary a revealing response to the anxiety of publishing her own second novel:

Night and Day flutters about me still, \& causes great loss of time. George Eliot would never read reviews, since talk of her books hampered her writing. I begin to see what she meant. I don't take praise or blame excessively to heart, but they interrupt, cast one's eyes backwards. . . I had rather write in my own way of "four Passionate Snails" than be, as K[atherine] M[ansfield] maintains, Jane Austen over again. (VW Diary 1: 316)

In another characteristic moment, when she writes in a letter to Margaret Llewelyn Davies of the task of reading all of Eliot for the 1919 article, she immediately moves from intimidating critical standards to the personality of the earlier author: "Its rather humiliating, reading other peoples novels. George Eliot fascinates me. Did your father know her? or was she too much under a cloud? Nobody called on her, so she says; and yet her virtue seems to me excessive-but there's no room left" (VW Letters 2: 385). It almost seems that Woolf would generate a whole novel (if there were room in the letter) about such a virtuous victim of scandal, such a learned and famous Maggie Tulliver, whom Woolf's father knew well.

When Woolf conjures up her most important predecessor she seems inevitably to follow the pattern of most readings of any woman novelist: she casts her as a literary heroine, creator of autobiographical heroines. It is one sad limitation of the colloquy I am initiating here that Woolf has all the last words, whereas Eliot must remain strangely silent on her successor. But if we were to borrow Rose Macaulay's license and allow the precursor to speak as the creator of the successorheroine, Eliot may be imagined to say (as she wrote of her heroines Dorothea, Romola, Maggie, and Gwendolen): "Virginia Woolf 'had that kind of beauty which seems to be thrown into relief by poor dress. ... She was open, ardent, and not in the least self-admiring; . . . her imagination adorned her sister with attractions altogether superior to her own.' She was reared in 'the world' of 'her father's books.' She wished to 'make [herself] a world outside [of love], as men do,' and there was 'an alarming amount of devil' in her; she was 'inwardly 
rebellious against the restraints of family conditions' but not one of the 'practically reforming women'; 'a soul burning with a sense of what the universe is not, and ready to take all existence as fuel, . . . nevertheless held captive by the ordinary wirework of social forms'; she was 'not going to do as other women did'; she was finally 'likely to seek martyrdom'" (M 5-7; R 104; MF 361, 328; DD 83, 168).

The portrait, of course, is more that of the composite Eliot heroine than of Woolf herself, but I submit that in general outline it would do not only for Eliot's supposed response to Woolf but for Eliot herself as well-not in either case the "real" woman, of course, but the "career author" recreated in a reading of her works (Booth 126-34). Woolf's portrayal of Eliot, as we shall see, corresponds with this model, as to some extent do all readings of these authors that grant their greatness. Woolf reconceived the Grand Old Woman of English Letters who preceded her: "The whole of the nineteenth century seems to be mirrored in the depths of that sensitive and profound mind which lies buried . . . under Mr. Cross's tomb" ("GE" [1926]). Aren't we tempted likewise to exhume Woolf as well as Eliot as a vessel of human history? How are we to reread Eliot and Woolf?

Not, it seems to me, by imposing a logical argument: my suggestions throughout this book for rereading Eliot and Woolf take the form of a series of colloquies or cross-breedings arranged in an associative narrative. First, in the rest of this introduction, I attempt to uncover the basis of the myths of Eliot and Woolf-the circumstances of their canonization, particularly in feminist discourse. It's lonely at the top: how many securely canonized women authors are there? How did they do it? Are we simply to admire the genius, like Shakespeare's, that from time to time lands in the wrong gender or class? Whatever the causes, the effects are manifest; the phenomena "George Eliot" and "Virginia Woolf" seem secure from literary oblivion-as far as we can see.

The question of how they have been read precedes, to my mind, the question of how they read the concepts of womanhood and tradition (taken up in Chapter 1), and subsequently, the question-addressed in the second chapter-of how they designed their works, personas, and careers to be read: what were the causes of their literary eminence? Chapters 3 and 4 focus on Eliot's and Woolf's revisions of history and of heroism, respectively - the two main axes of their feminist conception of greatness. The remaining chapters engage pairs of novels as parallel reinscriptions of the feminine in history. At successive stages in their careers (and here my narrative becomes chronological), Eliot and Woolf both speculated, first, on aristocratic heroines as 
stand-ins for the great women of letters, as leading ladies of historical romance (Romola and Orlando, Chapter 5). Then, chastening these individualistic fantasies, they wrote realistic histories of the common life with a conflicted feminist agenda, as private and public spheres, feminine and masculine, struggle for predominance (Felix Holt and The Years, Chapter 6). Finally, this struggle becomes impossible to ignore in the last novels, in which individual greatness and the feminine ideal, public history and the darker currents of private experience threaten to declare war, though the authors seek the arbitration of ancient myth (Daniel Deronda and Between the Acts, Chapter 7). With this trajectory in mind, I turn first to the biographical myth.

\section{The Canon and the Canonized}

I have been aware of a certain inevitability as well as improbability in this project: the inevitability of considering together the two most rounded and renowned English women of letters; and the improbability that a comparison will yield much more than certain striking similarities in literary biography. How unlikely it must seem that they have much in common: the female Victorian sage, with her intrusive philosophical narrator, and the "feminist-modernist" (Gubar, "Birth of the Artist," 39) with the disembodied voice, eddying rather than edifying. The contrast between these voices underscores the changing context of feminism and of literary modes over the years. A careful examination of these two profoundly related writers should help restrain a tendency to extrapolate from the circumstances of women novelists of the nineteenth century in England the supposedly universal circumstances of the woman writer. In many respects, the personas of Eliot and Woolf foil a desire to generalize about women writers.

The manly Victorian and the ladylike modern certainly went about their achievements in different spirits. Yet in their success they are not divided: they are among the few women writers ever to be welcomed into the canon without delay, though not without the usual fluctuations. As an outspoken feminist who eschewed the masculine narrative persona, Woolf not incidentally encountered resistance to her work as overrefined and elusive, as, in a word, ladylike. Eliot's literary persona can seem just the opposite, as Woolf remarked: "In fiction, where so much of personality is revealed, the absence of charm is a great lack [telling word!]; and her critics, who have been, of course, mostly of the opposite sex, have resented, half consciously perhaps, her deficiency in a quality which is held to be supremely desirable in 
women" ("GE" [1919] 152). For some decades after her death, Eliot's reputation sank under the ponderous image of the manly female sage. Yet the canonized personas of Eliot and Woolf have much in common besides the success that underlies these different styles.

Woolf was raised in Eliot's Victorian milieu, ${ }^{12}$ but coming later could more openly confront the obstacles in a woman's path toward literary eminence, whereas Eliot had to play the role of the exceptional being to whom the norms of her sex somehow never applied (Carroll, Heritage, 13-14; Beer, George Eliot, 26; D. Barrett 1-13). To be the sibyl, to be the first woman of the age, may have been a handicap for Eliot, as Woolf saw it, but she herself felt the strain of eminence, being "the only woman in England free to write what I like," yet "being a figure . . . being a martyr" to criticism (VW Diary 3: 43, 4: 251). Woolf's stance as outsider in society and insider in moments of being replicates in many ways Eliot's persona.

Readers of Eliot and Woolf have constructed many versions of these personas, most of them images of greatness, but some of them highlighting the lack attributed to womanhood. Eliot could be appropriated as a paragon of womanhood or a great man of letters; thus Mathilde Blind in 1883 published the laudatory George Eliot in the "Famous Women" series, but then in 1902 Leslie Stephen placed her among the "Men of Letters," where her womanhood became a glaring fault. Generations of biographies, guidebooks to Warwickshire artifacts, and editions of the complete works certify the great author's canonicity. Several editions of Eliot feature illustrations not of the author or of the text itself but of the aura of greatness: photographs of her houses, or of great men such as Goethe (the subject of a biography by George Henry Lewes), whose statue and portrait endorse a 1910 edition of Impressions of Theophrastus Such (Harper's Complete Works).

Woolf has yet to make it to gold-leaf "Complete Works," but biographies and guidebooks to Bloomsbury are hastening to outdo the Eliot pattern, while the monumental volumes of diaries, letters, and essays already exceed Eliot's remains, reminding us that the Victorians customarily destroyed their most personal effects to protect the image of greatness. Our tastes have changed; if we must love the great, we must have some intimacy with private failings, and Woolf has amply

\footnotetext{
${ }^{12}$ Through her father, whom Eliot consulted on details of college life for Daniel Deronda (Haight 476), Woolf knew many of her predecessor's eminent contemporaries. Henry James, for instance, visited at the Priory in 1869 and at the Stephen home in the 189os (Haight 416-17; Bell 1: 32). Woolf's great-aunt Julia Cameron brought a gift of photographs to the Priory and wanted to photograph Eliot (Haight 450); Virginia Woolf wrote an introduction to a volume of Cameron's work.
} 
documented her privacy. Not everyone has loved Woolf, of course, any more than Eliot's immediate successors loved her. Some still doubt Woolf's significance. An eccentric but perhaps authoritative example is Hugh Kenner, who sets Woolf in a dead-end tradition as heir to Henry James, with "no descendants." The editions of letters and diaries are "a fine catafalque" that claims, as she would not have done, "that she was her time's regnant sensibility" $(75,165-66)$. Though Woolf was eager enough to crown herself as the spirit of the age (and to laugh at such monarchy), Kenner is right to view the scholarly memorialization with suspicion. As Thomas Caramagno charges, Woolf may have been turned into a "Lady of Shallot [sic] . . more beautiful dead than alive" (10).

Much academic criticism prides itself on being less personal than the above biographical judgments, but the purest study of texts is governed by judgment of an author's worthiness on one scale or another. These days, no critic has to defend her choice to study Woolf, unless it be against charges of redundancy. Woolf is well entrenched in the academic battlefield: the MLA Bibliography for 1981 through March 1991 lists 732 items on her and 667 on George Eliot, who for decades was one of the three assuredly "major" English women writers (with Austen and Emily Brontë); each year the count of work on Woolf pulls farther ahead of the total for Eliot. Woolf has taken Eliot's place as a figure of intense biographical interest. The stir over Eliot's private life has subsided, while the political and formal aspects of her work seem to require the mediation of experts. In contrast, Woolf's revival has been sparked by the warm reception of her amply documented life and of her feminist politics, both of which have a wide if controversial appeal. ${ }^{13}$ Eliot seems more firmly than ever grouped with the great sages, conversing over a rather thin gruel of Feuerbach and Comte, though studies such as those by Graver, Myers, and Welsh (in 1984 and 1985) have succeeded in reviving her as an independent and complex social critic, while works like Barbara Hardy's 1959 The Novels of George Eliot: A Study in Form have long established her astounding control of structure and imagery.

\footnotetext{
${ }^{13}$ Eric Warner notes that he was slow to assemble the only centenary conference on Woolf in England (at Fitzwilliam College, Cambridge, 20-22 September 1982), and that otherwise the British media were silent on Woolf's centenary (1-3). American enthusiasm for Woolf has been seen by Quentin Bell and others as a misguided belief in Woolf's feminist commitment and literary importance. See Jane Marcus, "Quentin's Bogey," and Bell, "Reply." Marcus notes a lingering "undecidability" in Woolf's reputation in spite of "canonization"; The Waves has been included in the Cambridge Landmarks of World Literature (1986), but there is continuing hostility, mostly among male British critics ("Lycanthropy" 109, 102-3).
} 
Woolf has similarly required being rescued from exclusive masculine company, not that of the social philosophers but of the formalist innovators (Freedman 3-7). Recently, Jane Wheare has rightly challenged the formalist bias of earlier Woolf criticism: the neglect of Woolf's "dramatic" novels (e.g., The Years) by those who insist on Woolf as a modernist experimenter (Wheare 1-3; Black, "Life of Natural Happiness," 310). The dramatic novels reveal Woolf the realistic social commentator and feminist, as Wheare shows, but it is misleading to suggest that Woolf simply exploits realist conventions in these works. Woolf is as much a literary experimenter in a novel like The Years as she is a social commentator in a work like Between the Acts; the formal and the social innovator are one, much as "the personal is the political" (Cuddy-Keane, "Politics of Comic Modes," 273).

The same concert of political and formal elements appears in Eliot's work, as well as the same tendency of critics to lay claim to one or the other of these inseparable images of the great writer. Either she is aloft in the impersonal, apolitical ether of art, or she is muscling it out in the trenches of a Cause; in either case, certain aspects of the woman writer's persona become a liability. This is not the place to retrace the arguments in the tugs-of-war over these authors, but to point out that arbitrary divisions between formal, ideological, and biographical interests can be used to tear the writers apart.

Instead, many critics such as myself try to unite the different interests without arbitrarily reconciling them, implying that the contradictoriness itself is indicative of greatness-or of worthiness to be talked about. Ralph Freedman, taking stock of the battling versions of Virginia Woolf in 1980, wrote what could apply almost as well to Eliot as to Woolf: "She was both elitist and nonelitist, playful and earthbound, self-conscious about her art and socially conscious as well. If some critical opinion has become polarized to reflect her own dialectic, this is precisely the symptom of the condition that has returned her to the center of the literary stage" (8). ${ }^{14}$ The composite character described here, a kind of stage heroine who encompasses a textual dialectic as well as a dialectic of public responses, seems to be the generic Grand Old Woman of Letters. Her greatness, our willingness to watch her at center stage, depends on her own difference from herself, her doubling of appearances to meet the contradictory demands of her audience. Such a burden of personality, which I discuss more fully in

\footnotetext{
${ }^{14}$ Marcus in 1989 discerned a similar variety of personas: "an anarchist Woolf next to a feminist, the class-bound Woolf next to the class-conscious. The daughter obsessed with the mother next to the modernist deconstructor" ("Lycanthropy" 110).
} 
the second chapter, has subtly determined Eliot's and Woolf's changing roles in the canon.

Feminist criticism of Eliot and Woolf has further determined their canonicity by stressing the womanhood that once had to be cordoned off from their greatness. Of course, even before feminist criticism, few critics ever forgot that Eliot was a woman; thus I somehow picked up in college the insight that the harsh treatment of pretty Hetty Sorrel or Rosamond Vincy must be the revenge of an ugly woman. Gilbert and Gubar's Angel of Destruction, a vast improvement over Eliot as jealous hag, remains for many the true George Eliot, in contrast with a victimized Woolf who only harmed herself. ${ }^{15}$ In the last fifteen years or so, Woolf has far outstripped Eliot as an enabling foremother in the "female literary tradition." While Woolf's literary eminence has been perhaps as daunting to successors as Eliot's ${ }^{16}$ in general the response of literary women to Woolf has been grateful rather than rebellious. After all, Woolf has encouraging as well as restraining words for those coming after: if she had set out to nourish her daughters in feminist criticism, she could hardly have offered a richer source than $A$ Room of One's Own (Stimpson). Eliot has remained central; books of feminist readings, whether neo-Marxist, neo-Lacanian, or variously poststructuralist (e.g., Newton, Homans, Langbauer), will predictably contain a chapter on Eliot, but her presence is relatively passive: what can be done to her to make her a feminist? The Grand Old Woman of Victorian Letters counseled resignation, it seems: an ideal of selfless devotion especially recommended for women who have little choice. Woolf, by happy contrast, wrote two books avowedly addressing what in Eliot's day would have been called the Woman Question, and she wrote many articles on women writers; these writings provide volatile fuel for our contemporary feminist controversy. I take it as significant that Woolf, not Eliot, is invoked by feminists of every camp (e.g., Marshall; Showalter, "Feminist Criticism"; Moi; M. Barrett, "Ideology," 77), in spite of the fact that Woolf's feminism harks back to many of the tenets of Eliot's and other Victorians' belief in womanhood.

Both Eliot and Woolf have disappointed many feminists in their

\footnotetext{
${ }^{15}$ Recent works by Uglow, Dorothea Barrett, Taylor, and Beer have complicated the biographical image based on Cross's and Haight's defining works. Analogous revision of Bell's Woolf has been instigated by Gordon, DeSalvo, Abel, and others.

${ }^{16}$ Elaine Showalter draws on Woolf's "Professions for Women": "A woman writer must kill the Angel in the House. . . . For Charlotte Brontë and George Eliot, the angel was Jane Austen. For the feminist novelists, it was George Eliot. For mid-twentiethcentury novelists, the Angel is Woolf herself" (Literature 265). See Marcus's corrective of Moi's reading of Showalter on Woolf ("Lycanthropy" 103).
} 
appeal to womanly influence, in their somewhat patronizing views of women writers, and in their implicit loyalties to tradition and explicit distrust of political action (Showalter, "Greening," Sexual Anarchy, 5775, and Literature, 264-65, 280-282; Gilbert and Gubar, Madwoman, 466; Moers 194; Stimpson 135-38). If feminist critics concur in canonizing Eliot and Woolf as great women of letters, how do they account for these disappointing features in the authors' ideology?

Taking a cue from Woolf, feminist critics often reproach Eliot's works for their narrow conception of woman's sphere: her heroines tragically submerge themselves in familial duty (Z. Austen 549-51). Yet Woolf herself is open to the charge not only of privilege (easy for her to say, £500 a year and a room of one's own!) but also of resorting to the strategies of feminine influence. Rather than objecting to her portrayal of women (count her lesbians and spinsters!), some of Woolf's successors deplore the polite manner of her feminist writings. A Room of One's Own offends a certain feminist commitment by suppressing anger (Rich, "When We Dead Awaken," 37; M. Barrett, Introduction, 20), while Three Guineas, so openly angry as to seem "hysterical," appears to invite "educated men's daughters" to secede from the politics of their menfolk as though it were a matter of withdrawing from the port and cigars after dinner. ${ }^{17}$

Such distrust of Woolf's manifestos may derive from the lingering odor of Victorian feminine sanctity about them. Earnest feminists may feel they are being handed the kind of "woman's mission" sop that Eliot seems to dispense in the Finale of Middlemarch - though these feminists may themselves be heirs to the ideology of influence, arguing for example that we would all be better off for a return of matriarchy or a polity of mutuality rather than domination. Woolf's conception of the feminine does to an extent harmonize with Eliot's, as I will show, while her novels record much the same outlook as Eliot's on woman's narrow sphere. Feminists who believe in political activism and an eradication of difference are rightly suspicious of Woolf's traditional brand of feminism. And yet many of them rely on her as a predecessor, much as Woolf, critical of Eliot's masculine persona and refusal to create a heroine of Eliot's own stature, drew on the most lauded Victorian woman novelist as a guide to resist as well as follow.

The mixed terms in which Eliot and Woolf have been canonized,

\footnotetext{
${ }^{17}$ Showalter coincides with Q. D. Leavis ("Caterpillars of the Commonwealth Unite!") in charging that in Three Guineas Woolf is out of touch with ordinary women, though Showalter would ask for more propaganda rather than less. Both critics center on Woolf's personality: a heavily diagnosed invalid with a "deadly . . . disembodied" "vision of womanhood" (Showalter, Literature, 294-97). See Minow-Pinkney 187-88.
} 
particularly in feminist criticism, call for a study such as this, which reconsiders not only the two authors in light of each other but also the critical and canonical standards. Thus the examination of Eliot's and Woolf's versions of feminism, while it throws new light on an important feminist tradition, also challenges the categories that have recently been imposed on feminist theory, inviting an eclectic method. From one point of view it appears that these writers could be differentiated according to the feminist theoretical treatment they invite: Eliot the Anglo-American empiricist mode with its preference for nineteenth-century realism, and Woolf the French psycholinguistic school with its privileging of modernist or postmodernist texts. ${ }^{18}$ But just as many critics have challenged the geographical categorization of AngloAmerican and French feminisms, I would question the utility of aligning Eliot with a naive empiricism and Woolf with an enlightened awareness of the contingencies of discourse. In spite of Woolf's skepticism about biographical truth and method, she like her "Anglo-American" heirs promotes the historical quest for maternal sources of meaning (however deferred); her reading of Eliot and of other women writers of the past anticipates the search for spiritual mothers by writers such as Alice Walker (who almost inevitably quotes $A$ Room of One's Own at length; 235, 239-40).

At the same time, however, Woolf may be championed as a pioneer of écriture feminine (Marcus, Languages, 13, 170) or as an outsider strangely allied to whatever male modernists or postmodernists (Joyce or Proust, Derrida or Lacan) the cosmopolitan feminist theorists invoke. ${ }^{19}$ Eliot in turn can be shown to haveanticipated deconstruction in figuring language as a web of metaphor strung on illusory difference, "pinched into its pilulous smallness" by the touch of interpretation (M 16). Moreover, Daniel Deronda, for instance, figures women as "other," associated with the oppressed (colonies) and the repressed (the unconscious) (Hertz; C. Chase; Graver 224-43). Significant as distinctions among feminist schools may be for some purposes, in this book I make no attempt to segregate them, though clearly I read Eliot and Woolf for the most part through the lens of a feminist criticism they helped to form, often called "liberal" or "Anglo-American."

\footnotetext{
${ }^{18}$ Just as the origins of psychoanalysis may be linked to the probing of the unconscious in novels such as Eliot's, later psycholinguistic innovations on Freud could be seen as indebted to modernist experiments in the disintegration of discourse and consciousness. As if to confirm this, Cixous and Kristeva invoke modern writers such as Woolf and Joyce. See Minow-Pinkney on Cixous and Woolf $(10,15)$ and Kristeva and Woolf $(23)$. See also Gilbert, "Introduction: A Tarantella of Theory," xv.

${ }^{19}$ Jacobus and Homans show how readily Eliot or Woolf can be adapted to psycholinguistic theory, turning the canon of Anglo-American feminism francophile.
} 
My readings render Woolf more Victorian and Eliot more modern (and feminist) than many readers will comfortably allow. Although numerous readings of Woolf have highlighted her Victorian origins or qualities (e.g., Beer, Past, 117-82; Hill; Marcus, Languages; McLaurin, Woolf; Meisel; Paul; Rosenbaum), and some have noted her debt to Victorian conservative feminism, most have assumed Woolf's own stated view that her most valuable contribution is that of "novelty." Indeed, without the modernist credentials, she might have been viewed, at least temporarily, as another faded Rose Macaulay. I believe, however, that an alignment of Woolf with Eliot, and particularly with Victorian gender ideology, is not only one of the most instructive and most neglected ways to view Woolf now, but also a way to revive rather than eulogize her, freeing her from the exclusive company of Joyce, T. S. Eliot, and other modernist worthies as well as from the burden of being everybody's favorite feminist. ${ }^{20}$

There are of course pitfalls in placing eminent women writers in a new feminist canon. I am wary of the element of nostalgia in feminist studies of nineteenth-century women authors, as well as in the cult of Woolf, though I do not automatically repudiate nostalgia (or avoid it even when I try). The search for a mother-past, like Lily Briscoe's forsaken cry for Mrs. Ramsay ("to want and not to have" [TL 266]), can be a dubious quest, reinstating masculinist desire for Woman. But if Mrs. Ramsay, or the woman writer of the past we choose to search for, is understood as Eliot's and Woolf's writings encourage us to understand character, not as a fixed center of meaning but as a deferred process, the historical-biographical quest itself may be a process that will answer feminist purposes (Gilbert and Gubar, No Man's Land 1: xi-xii). If, moreover, we can laugh off our inclination to rescue work-that is, our desire to rescue women writers of the past for feminist respectability in the manner of genteel Victorians redeeming women of the streets-we may be able to reinterpret women's literary history and the history of feminist thought, reshaping it for purposes defined as "respectable" or worthwhile in our day.

Our rescue work in the female literary tradition often seems too eager to wash away the sins of history, that is, the particular historical conditions that render women different from each other in spite of their common sex and gender. Until recently, much feminist scholarship has been devoted to honoring female heroes, proving their great-

\footnotetext{
${ }^{20}$ Modernism ain't what it used to be: by now many eminent female modernists have escaped the shadows of T. S. Eliot and Ezra Pound to form their own marginal center. Works by Shari Benstock, Mary Lynn Broe and Angela Ingram, and Bonnie Kime Scott in particular have shifted the canon.
} 
ness because they too speak for "us" all. By the 1990s, one really ought to be beyond that, ought to be rescuing more marginal voices. But there are still many silences in the few already dominant women's voices, and I listen for differences as well as concurrence within these. I have no stake in denying the significant changes in literary climate for these two authors, or in denying the exclusivity of that middleclass, English climate. Nor would I wish to ask readers to forget that Marian Evans Lewes Cross died in 1880, wholly innocent of the two World Wars and the myriad other factors that created a sense of the "modern," let alone unaware of the birth of Virginia Woolf in 1882. In the pages that follow, however, I am willing to let George Eliot and Virginia Woolf seem to speak to each other or even at times in unison, not as universal, ahistorical voices but in all their idiosyncracy and frequent dissonance. In this performance, I am drawn as so many feminist critics have been to the mode of Woolf's own biographical criticism. According to Barbara Currier Bell and Carol Ohmann, Woolf often "personifies the works of a writer: so she presents us not with a series of texts but with someone, a man or a woman" (their emphasis; 55). Bell and Ohmann make clear that for Woolf this personification is the essence of the biographical author contained in the texts, not a waxwork of the real personage who wrote them.

These authorial personas are usually read as offering contradictory responses to the Woman Question, Eliot conservative and Woolf radical. But feminist readers have often struggled with the hard fact of each author's skepticism about direct political action in spite of her close association with activists. This skepticism is in keeping with the feminist tradition in which I place both Eliot and Woolf. This tradition, upholding feminine influence in opposition to masculine authority, has generally confined its political action to the realm of rhetoric in the most honorable sense, that is, to teaching, art, and writing of all kinds, not (or not simply) from a ladylike reluctance to make a scene. Force is always wrong, we are shown in the satire of the rabble in Felix Holt and of Rose Pargiter's suffragette brick-throwing in The Years. The vote means little in the face of inequalities of education and opportunity-so the private and public writings of Eliot and Woolf maintain.

The ideology of influence as I characterize it is certainly more conservative than the agenda of most feminists in the United States in the 1990 (the pro-choice and pro-influence positions seem irreconcilable, for example), but the influence of that ideology itself has far from disappeared. Hence Eliot and Woolf are important to an understanding of feminist traditions. They articulate a skepticism about political 
reform based on a belief in the priority of private experience over public life that has remained with the movement. Many feminists now are persuaded that legislation will never shake the dominance of men in private relations; as Mary Evans puts it, "The universal subordination of women . . . is unlikely to be altered by changes in legal and administrative practices." Indeed, the slogan "the personal is political" should be seen as a late-twentieth-century equivalent of the demonstration in nineteenth-century novels that political reform is insufficient: the power plays of home life are the foundation of the state (Evans 15-17). ${ }^{21}$

One of the great benefits of feminist analysis has been to provoke readers to storm the mental barricades that separate history and the political world of men from everyday life and the domestic world of women, to challenge, as Eliot's and Woolf's writings do, the priority of public politics over private, or even to challenge the clear distinction between what is public and what is private. But there is always the risk of jumping over to the underprivileged side and adding sofa cushions and kitchen chairs to the barricades, thus reinforcing the dualism (and inevitable hierarchy) of public/private, male/female. The suspicion that demonstrations or legislative reforms may be simply new moves in a game always already fixed ought to warn us against assuming that those who abstain from playing necessarily approve things as they are. ${ }^{22}$ Indeed, a certain radical glamor has been cast over the (inevitably political) move of abstention by French theorists who, like Eliot and Woolf, eschew the term "feminism" or hold aloof from the movements for parity for women with men in law or work. These French theorists compellingly charge that the desire for equality reinforces the phallocentric discourse of the "same"; liberation movements are bourgeois efforts to invert the dualist hierarchy of masculine/feminine without escaping hierarchical dualism (e.g., Irigaray, This Sex, 30-33). Yet this sophisticated argument is directed by women with Ph.D.s against women whose bedfellows are not Nietzsche, Heidegger, Derrida, or Lacan. Abstention, then, may often be the

\footnotetext{
${ }^{21}$ Claudia Johnson suggests that, in the aftermath of the French Revolution, simply to portray female independence was to express revolutionary sympathies (xxiii-xxv). In another regard, gender relations are more far-reaching than "politics"; Simone de Beauvoir belatedly realized sexism will not vanish after the ever-postponed revolution (Moi 91-92). See MacKinnon 234-35; Nicholson.

${ }^{22} \mathrm{An}$ entire book could be written on the current phenomenon of critics rushing to make their ideological affiliations explicit and beating the bushes for political actions by writers of earlier times, while themselves busily writing, teaching, going to an occasional rally, or sending in their check to Amnesty International. Eliot and Woolf were after all rather busy writing, and agonizing over it to boot.
} 
ironic privilege of women-such as Eliot and Woolf, not incidentallywhose access to the patriarchal tradition or counter-tradition was undoubtedly hard-won and would not have been possible without earlier reform movements. Nevertheless, the few women so privileged seem determined to resist being lumped with ordinary women.

We can see a similar conflict in a bizarre minor tradition within academic feminist criticism, a tradition of acknowledgments of the "others," from Annette Kolodny's reference to "the millions of women who labor in poverty" (163), to Moi's subsumption of black and lesbian criticism in a text on feminist theory as a whole $(86-87) .{ }^{23}$ Often it appears that feminist academics, like Eliot and Woolf, are finding voice out of women's general silence: keep the few women in the men's club by refusing admittance to the shrill petticoat (or radical chic) rabble. We should be wary of this familiar move-and I perceive it in my own discussion of two canonical writers-but it is not clear to me that the politically laudable choice of scholarly subject or theoretical vocabulary leads to more rapid defeat either of destructive ideology or of the oppression intertwined with it. The written line may bear some resemblance to a trench, but most of us know not to flatter ourselves with the analogy. The written "front" is not imaginary, but defers any victories to future consciousness; meanwhile the student who has been raped by her roommate's boyfriend, the secretary who can't collect child care payments from her ex-husband, the overcrowded shelter for battered wives here in town are no better off if I earn the order of merit on the page. Knowing that our gratifications are perforce delayed may drive us in frustration to attack each other's jargon or apparent lack thereof, but energies can be better directed. I admire and engage with "theory" without wishing to be it, and in many ways I infuse a poststructuralist critique of phallocentrism in my study of Eliot's and Woolf's eccentric or alter-native evocations of identity, history, and heroism or greatness. But my sympathies lie more with the far-from-neutral tone and perspective of the far-fromunivocal liberal tradition that fostered Eliot and Woolf.

\footnotetext{
${ }^{23}$ Other instances of awkward bows to those outside the white, middle-class heterosexual enclave include Patricia Meyer Spacks's notorious disclaimer in The Female Imagination (see Smith 172; Gardiner et al. 639-40; and Carby 9-10) and the affirmative-action table of contents of Showalter's The New Feminist Criticism (one article about lesbian criticism, two about black and lesbian criticism). It is easier to attack the effects of privilege than to avoid them, however. We should also grant that feminist critics have been more responsive than some scholarly guilds to charges of exclusivity, as is indicated by Showalter's inclusion of Smith's article in her own edition. Moreover, Spacks's was one of the first admissions that "we" were not speaking from a universal platform; she might have offended more if she had been more of an integrationist.
} 
In resisting the compulsion to choose sides, I may not wholly please either. My point in what follows is to keep negotiations open; the conflicting loyalties and insights of Eliot and Woolf can never be reduced to complicity with patriarchal discourse and cultural privilege. Self-contradictory, they strove for the truth universally acknowledged at the same time that they demolished the One supposed to know such contested truth. And like most practicing academic feminists, they sought to transform the discourse in which human beings in all their variety apprehend women and men, while themselves purchasing a place as women of letters in a tradition blinded to difference. 